\title{
Intracranial calcification and seizures in Down syndrome
}

\author{
Prateek Kumar Panda 지 , Aman Elwadhi, Indar Kumar Sharawat
}

Pediatric Neurology Division Department of Pediatrics, All India Institute of Medical Sciences, Rishikesh, India

\section{Correspondence to} Dr Indar Kumar Sharawat; sherawatdrindar@gmail.com

Accepted 15 April 2021

Check for updates

(c) BMJ Publishing Group Limited 2021. No commercial re-use. See rights and permissions. Published by BMJ.

To cite: Panda PK, Elwadhi A, Sharawat IK. BMJ Case Rep 2021:14:e243180. doi:10.1136/bcr-2021-

243180

\section{DESCRIPTION}

A 13-year-old girl with Down syndrome (DS) presented with one episode of new-onset, unprovoked generalised tonic-clonic seizure at home 1 hour before, lasting for around $5 \mathrm{~min}$. The child had an open mouth, flat facial profile, mongoloid slants, simian crease and saddle gap in toes suggesting a Down phenotype. But cardiovascular, respiratory and abdominal examination were within normal limits. Apart from a history of intellectual disability, postictal drowsiness and a Down phenotype, no other physical abnormality could be detected on physical examination. Complete blood count, blood sugar, serum sodium, potassium, phosphate, liver and renal function tests were within normal limits.

Her serum total $(5.4 \mathrm{mg} / \mathrm{dL}$; normal $8.6-10.4 \mathrm{mg} /$ $\mathrm{dL})$ and ionised $(0.47 \mathrm{mmol} / \mathrm{L}$; normal 1.15 $1.30 \mathrm{mmol} / \mathrm{L})$ calcium and vitamin $\mathrm{D}(11.2 \mathrm{ng} /$ $\mathrm{mL}$; normal $20-40 \mathrm{ng} / \mathrm{mL}$ ) levels were low. While serum alkaline phosphatase (1245 IU/L; normal $44-147 \mathrm{IU} / \mathrm{L})$ and parathyroid hormone $(282 \mathrm{pg} /$ $\mathrm{mL}$; normal $11-51 \mathrm{pg} / \mathrm{mL}$ ) levels were high. Her serum phosphorus levels were within normal ranges $(4.8 \mathrm{mg} / \mathrm{dL}$; normal $4-7 \mathrm{mg} / \mathrm{dL})$. There was no clinical or radiological evidence of rickets. However, Erb's sign could be elicited clinically. Noncontrast CT of the head showed intracranial calcifications (figure 1). Her electroencephalogram was normal. The diagnosis of DS with hypocalcemic seizures caused by vitamin D deficiency with secondary hyperparathyroidism and basal ganglia (BG) calcification was made. She was started on intravenous calcium gluconate followed by oral calcium and calcitriol supplementation. There was no further recurrence of seizures and on follow-up, the serum calcium and vitamin D level were normal.

Patients with DS have a higher incidence (around $8 \%)$ of febrile and afebrile seizures than the general population. While $47 \%$ of seizures in DS are focal seizures, $21 \%$ only are generalised tonic-clonic, and the remaining are mainly epileptic spasms. However, seizures in DS follow a bimodal distribution with $40 \%$ of patients develop seizures before 1 year and $40 \%$ develop after 30 years, thus making new-onset seizures in adolescents with DS rare. ${ }^{1}$ Similarly, vitamin D deficiency has been reported to be more prevalent in children with DS, but in adolescents, no large studies available. ${ }^{2}$ New-onset unprovoked hypocalcemic seizures in adolescents with DS have been extremely rare. We could find only one such case in existing literature who also had coeliac disease, which leads to malabsorption and secondary vitamin D deficiency. ${ }^{3}$
Hypoparathyroidism and pseudohypoparathyroidism predispose to $\mathrm{BG} /$ intracranial calcification by deposition of calcium phosphate crystals in cerebral tissue, and the same mechanism has been proposed for other causes of chronic hypocalcemia causing BG/intracranial calcification. But vitamin D deficiency causing intracranial calcification has only been reported rarely in the literature. ${ }^{4}$ As such DS is not commonly considered as one of the common causes of BG/intracranial calcification, but an autopsy-based study has detected BG microcalcification in 13 out of 33 DS cases of 1-60 years of age, including four paediatric patients. While three of them had mild calcification of BG, one paediatric patient had massive BG calcification. A similar morphometric CT-based study showed $10.7 \%$ out of 56 patients with DS (0-37 years) had bilateral BG calcification. Calcification predominantly involved globus pallidus and sometimes the head of the caudate nucleus. ${ }^{5}$ Although most cases had no symptoms attributable to calcification, occasional cases presented with movement disorders like dystonia, choreoathetosis and dysarthria. Even this BG calcification has been proposed as a result of premature ageing in DS or might be a result of previous unnoticed anoxic damage to brain tissues, both of which are more prevalent in cases with DS. ${ }^{5}$ However, the exact pathogenesis of calcification in DS is not clear and such association with hypocalcemia, vitamin D deficiency and seizures is being reported for the first time in the literature, to the best of our knowledge. This case underscores the

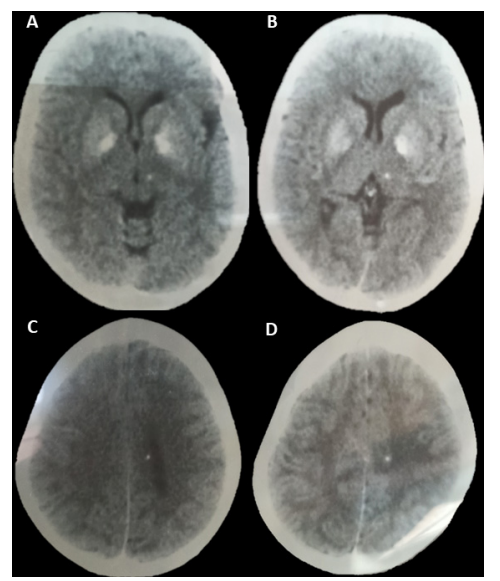

Figure 1 Non-contrast CT of the head. Axial sections (A-D) showed symmetrical hyperdense lesions on bilateral putamen and globus pallidi ( $A$ and $B$ ) suggestive of calcification. Tiny, calcified foci were also seen in the left midbrain (A), left thalamus (B) and left centrum semiovale (C and D). 
importance of suspecting hypocalcemia even in adolescents with DS having seizures and thus getting serum ionised calcium level done before starting antiepileptic drugs. Also, this case suggests subclinical/clinical hypocalcemia and vitamin D deficiency, as a new pathogenetic mechanism behind the increased prevalence of BG/intracranial calcification in cases with DS.

Our case had secondary hyperparathyroidism, and hyperphosphatemia is one of the triggers for secondary hyperparathyroidism as occurs in patients with renal disease. Our patient had normal phosphate level despite secondary hyperparathyroidism most probably due to the reason that secondary hyperparathyroidism was triggered by vitamin $\mathrm{D}$ deficiency, and vitamin D deficiency is associated with low serum calcium and phosphate levels in a considerable proportion of cases. ${ }^{6}$

The reason for vitamin D deficiency was most probably poor nutrition in our case, which is quite common in cases with DS due to swallowing difficulty, the poor muscle tone of muscles involved in chewing and association with gastro-oesophageal reflux in few cases. The parents also belonged to a lower socioeconomic status. Hypocalcemia is known to cause seizures by increasing neuronal excitability due to reduced extracellular

\section{Learning points}

- Patients with Down syndrome (DS) have a higher incidence of seizures than the general population.

- New-onset unprovoked hypocalcemic seizures in adolescents with DS are rare.

- Vitamin D deficiency causing intracranial calcification is rarely reported in the literature.

- DS is not commonly considered as one of the common causes of basal ganglia/intracranial calcification. concentration of calcium rather than depleted intracellular levels and thereby reducing seizure threshold. The existing literature and the current case report suggest that there could be a possible association between vitamin D deficiency and intracranial calcification in patients with DS. But prospective follow-up studies with a large sample size are needed to establish a definite causal association between these two.

Contributors PKP, AE: patient management, literature search, data analysis and initial draft manuscript preparation. IKS: literature search, data analysis and critical review of the manuscript. He will act as a guarantor of the manuscript.

Funding The authors have not declared a specific grant for this research from any funding agency in the public, commercial or not-for-profit sectors.

Competing interests None declared.

Patient consent for publication Parental/guardian consent obtained.

Provenance and peer review Not commissioned; externally peer reviewed.

\section{ORCID iDs}

Prateek Kumar Panda http://orcid.org/0000-0001-7831-9271

Indar Kumar Sharawat http://orcid.org/0000-0002-7003-7218

\section{REFERENCES}

1 Rahman MM, Fatema K. Seizures in Down syndrome: an update. Mymensingh Med J 2019:28:712-5

2 Del Arco C, Riancho JA, Luzuriaga C, et al. Vitamin D status in children with Down's syndrome. J Intellect Disabil Res 1992;36:251-7.

3 Sharawat IK, Dawman L. Bone mineral density and its correlation with vitamin D status in healthy school-going children of Western India. Arch Osteoporos 2019;14:13.

4 Korkmaz HA, Dizdarer C, Ecevit CO. Hypocalcemic seizure in an adolescent with Down syndrome: a manifestation of unrecognized celiac disease. Turk J Pediatr 2013:55:536-8.

5 Wisniewski KE, French JH, Rosen JF, et al. Basal ganglia calcification (BGC) in Down's syndrome (DS)--another manifestation of premature aging. Ann N Y Acad Sci 1982:396:179-89.

6 Sharawat I, Sitaraman S, Dawman L. Prevalence of vitamin D deficiency among healthy school children in Jaipur district, Rajasthan, India. Int J Pediatr 2015;3:801.

Copyright 2021 BMJ Publishing Group. All rights reserved. For permission to reuse any of this content visit

https://www.bmj.com/company/products-services/rights-and-licensing/permissions/

BMJ Case Report Fellows may re-use this article for personal use and teaching without any further permission.

Become a Fellow of BMJ Case Reports today and you can:

- Submit as many cases as you like

- Enjoy fast sympathetic peer review and rapid publication of accepted articles

- Access all the published articles

Re-use any of the published material for personal use and teaching without further permission

Customer Service

If you have any further queries about your subscription, please contact our customer services team on +44 (0) 2071111105 or via email at support@bmj.com.

Visit casereports.bmj.com for more articles like this and to become a Fellow 